\title{
Immunolabeling of Proteins in situ in Escherichia coli K12 Strains
}

Nienke Buddelmeijer ${ }^{1}$, Mirjam Aarsman ${ }^{2}$ and Tanneke den Blaauwen ${ }^{3^{*}}$

\author{
${ }^{1}$ Institute Pasteur, Institute Pasteur, Paris, France; ${ }^{2}$ (Retired) Bacterial Cell Biology Department, \\ University of Amsterdam, Amsterdam, The Netherlands; ${ }^{3}$ Bacterial Cell Biology Department, \\ University of Amsterdam, Amsterdam, The Netherlands \\ *For correspondence: t.denblaauwen@uva.nl
}

[Abstract] This protocol was developed to label proteins in bacterial cells with antibodies conjugated to a fluorophore for fluorescence microscopy imaging. The procedure is optimized to minimize morphological changes and also to minimize the amount of antibodies needed for the staining. The protocol can also be used with primary antibodies conjugated to a fluorophore. The method has been verified extensively (van der Ploeg et al., 2013), but it should be noted that one case in Caulobacter crescentus (Hocking et al., 2012) has been reported in which the localization of a protein changed upon fixation by formaldehyde/glutaraldehyde. However, the localization of the same protein in E. coli did not change.

\section{Materials and Reagents}

1. Gram-negative bacteria (the protocol is developed for Escherichia coli, but it also works on other species)

2. Formaldehyde (FA) (Sigma-Aldrich, catalog number: 47608)

3. Glutaraldehyde (GA) (Merck KGaA, catalog number: 1-04239-0250)

4. Tween-20 (Sigma-Aldrich, catalog number: P9416-100ml)

5. Triton X-100 (Merck KGaA, catalog number: 1.08643.1000)

6. EDTA (Sigma-Aldrich, catalog number: ED255)

7. Lysozyme (Sigma-Aldrich, catalog number: L6876)

Note: The lysozyme is dissolved at $100 \mu \mathrm{g} / \mathrm{ml}$ in the PBS pH 7.2 with $5 \mathrm{mM}$ EDTA ready to use $1 \mathrm{ml}$ aliquots and stored at $-20^{\circ} \mathrm{C}$. After using it the leftover is discarded.

8. Blocking reagents (F. Hoffmann-La Roche, catalog number: 1096176))

9. Cy3-AffiniPure Donkey Anti-Rabbit IgG $(H+L)$ (Jackson ImmunoResearch, catalog number: 711-165-152)

Note: Minimal cross-reaction to Bovine, Chicken, Goat, Guinea, Pig, Syrian Hamster, Horse, Human, Mouse, Rat and Sheep serum proteins. The in buffer freeze-dried Cy3 labeled secondary antibodies are dissolved in $\mathrm{H}_{2} \mathrm{O}$ to a final concentration of $1.5 \mathrm{mg} / \mathrm{ml}$ 
and aliquoted as $20 \mu \mathrm{l}$ samples. Once thawed the secondary antibodies are stored at 4 ${ }^{\circ} \mathrm{C}$. After one month take a new sample from the $-20^{\circ} \mathrm{C}$.

10. PBS buffer ( $\mathrm{pH} 7.2)$ (see Recipes)

\section{Equipment}

1. Shaking incubator to grow bacteria

2. $500 \mu \mathrm{l}$ or $1 \mathrm{ml}$ tubes (Eppendorf)

3. $50 \mathrm{ml}$ Tubes (Greiner Bio-One $\mathrm{GmbH}$, catalog number: 227261) (Alternative Sorval SS34 tubes)

4. Eppendorf centrifuge $5804 \mathrm{R}$ (Alternative Sorval centrifuge for SS32 rotor)

5. Eppendorf centrifuge (cooled)

6. Shaking incubation block for Eppendorf tubes

\section{Procedure}

A. Permeabilization of the cells

1. Escherichia coli cells (LMC500 strains) are grown in medium at $28-42{ }^{\circ} \mathrm{C}$ and fixed in 2.8\% FA and $0.04 \%$ GA as follows: $12.2 \mathrm{ml}$ culture with $\mathrm{OD}_{450}$ of 0.2 (or $\mathrm{OD}_{600}$ of 0.3 ) is mixed by addition of a pre-mixture of $1 \mathrm{ml} 37 \%$ FA and $21 \mu \mathrm{l} 25 \%$ GA while shaking in the water bath used for growth. Transfer the culture to $50 \mathrm{ml}$ Greiner centrifuge tubes.

Note: It is recommended keeping the $O D_{600}$ below 0.3 for optimal exponential growth in rich medium and the $O D_{450}$ below 0.2 for minimal medium.

2. Incubate $15 \mathrm{~min}$ at room temperature (RT) standing and centrifuge at $4,000 \times g$ for 10 $\min$ at RT.

3. Wash the cells once in 1 volume PBS ( $\mathrm{pH} 7.2)$.

4. Resuspend the pellet in $150 \mu \mathrm{PBS} \mathrm{pH} 7.2$ and transfer the cells to $500 \mu \mathrm{l}$ Eppendorf tubes.

5. Pellet the cells by centrifugation at $4,500 \times g(7,000 \mathrm{rpm})$ for $5 \mathrm{~min}\left(\mathrm{RT}\right.$ or $\left.4{ }^{\circ} \mathrm{C}\right)$ and wash twice in $150 \mu$ PBS ( $\mathrm{pH} 7.2$ ). The cells can be stored up to a month at $4{ }^{\circ} \mathrm{C}$.

6. All subsequent steps are performed in $150 \mu$ (less is also possible) and all centrifugation steps are at $4,500 \times g(7,000 \mathrm{rpm})$ for $5 \mathrm{~min}$ at RT or $4{ }^{\circ} \mathrm{C}$.

7. Incubate the cells in $0.1 \%$ Triton X-100/PBS pH 7.2 standing for 45 min at RT.

8. Wash the cells three times in PBS ( $\mathrm{pH} 7.2)$.

9. Incubate the cells in PBS ( $\mathrm{pH} \mathrm{7.2)} \mathrm{containing} 100 \mu \mathrm{g} / \mathrm{ml}$ lysozyme and $5 \mathrm{mM}$ EDTA for 45 min (or $30 \mathrm{~min}$ in case of cell wall mutants) at room temperature.

10. Wash the cells three times in PBS (pH 7.2). 
B. Labeling procedure

1. Block non-specific binding sites by incubating the cells standing or shaking in $0.5 \%(\mathrm{w} / \mathrm{v})$ blocking reagents in PBS (pH 7.2) for 30 min at $37^{\circ} \mathrm{C}$.

2. Incubate with primary antibody (rule of thumb 10 times more concentrated than needed for immunoblotting) diluted in blocking buffer, $1-2 \mathrm{~h}$ at $37^{\circ} \mathrm{C}$ in shaking incubator (minimal incubation time $30 \mathrm{~min}$, maximal incubation time over night at $4{ }^{\circ} \mathrm{C}$ depending on the antibodies).

3. Wash the cells three times in PBS (pH 7.2) containing $0.05 \%(\mathrm{v} / \mathrm{v})$ Tween-20.

4. Incubate with secondary antibody donkey- $\alpha-$ rabbit-CY3 (guarantee no cross reactivity against $E$. coli) diluted in blocking buffer $(1: 600)$ for 30 min at $37^{\circ} \mathrm{C}$.

Note: Centrifuge the antibody in blocking solution for 1 min at max speed to remove clumps of dye before adding it to the cells.

5. Wash the cells three times in $150 \mu \mathrm{PBS}(\mathrm{pH} 7.2) / 0.05 \%$ Tween-20.

6. Wash the cells once in in $150 \mu \mathrm{l}$ PBS.

7. Resuspend the cells in PBS.

Notes:

a. Adjust the volume to the amount of cells (usually $20 \mu \mathrm{l}$ ), i.e. the cell concentration should be high enough for the microscopic analysis.

b. Antisera against E. coli proteins can very conveniently be separated from contaminating IgG by incubating the serum against a strain that has the gene of interest deleted using the same procedure as above. Subsequently the non-bound IgG is used for the incubation with the wild type strain. If the protein of interest is essential, the serum has to be affinity purified against the pure protein of interest.

\section{Notes}

Fixation of the bacterial culture (either by formaldehyde/glutaraldehyde or by ethanol or methanol), which is essential for the immunolabelling procedure, gives an osmotic shock to the cells. The localization of membrane bound or membrane associated proteins or of cytosolic proteins is not affected by the osmotic shock. However, freely in the periplasm diffusing proteins can be shocked to the cell poles during fixation. Therefore, we do advise to verify the localization of periplasmic freely diffusing protein by analysis of the localization of fluorescent protein fusions to these proteins in combination with life imaging.

\section{$\underline{\text { Recipes }}$}

1. PBS buffer (pH 7.2) (per L) 
$140 \mathrm{mM} \mathrm{NaCl}$

$27 \mathrm{mM} \mathrm{KCl}$

$10 \mathrm{mM} \mathrm{Na} 2 \mathrm{HPO} 4 \cdot 2 \mathrm{H} 2 \mathrm{O}$

$2 \mathrm{mM} \mathrm{KH}_{2} \mathrm{PO}_{4}$

Note: PBS should always be super-sterile.

\section{Acknowledgments}

The protocol described has been used in the following publications: Blaauwen et al. (1999); Aarsman et al. (2005); Potluri et al. (2010); Typas et al. (2010); Banzhaf et al. (2012); van der Ploeg et al. (2013) and Egan et al. (2014).

\section{References}

1. Aarsman, M. E., Piette, A., Fraipont, C., Vinkenvleugel, T. M., Nguyen-Disteche, M. and den Blaauwen, T. (2005). Maturation of the Escherichia coli divisome occurs in two steps. Mol Microbiol 55(6): 1631-1645.

2. Banzhaf, M., van den Berg van Saparoea, B., Terrak, M., Fraipont, C., Egan, A., Philippe, J., Zapun, A., Breukink, E., Nguyen-Disteche, M., den Blaauwen, T. and Vollmer, W. (2012). Cooperativity of peptidoglycan synthases active in bacterial cell elongation. $\mathrm{Mol}$ Microbiol 85(1): 179-194.

3. Den Blaauwen, T., Buddelmeijer, N., Aarsman, M. E., Hameete, C. M. and Nanninga, N. (1999). Timing of FtsZ assembly in Escherichia coli. J Bacteriol 181(17): 5167-5175.

4. Egan, A. J., Jean, N. L., Koumoutsi, A., Bougault, C. M., Biboy, J., Sassine, J., Solovyova, A. S., Breukink, E., Typas, A., Vollmer, W. and Simorre, J. P. (2014). Outer-membrane lipoprotein LpoB spans the periplasm to stimulate the peptidoglycan synthase PBP1B. Proc Natl Acad Sci U S A 111(22): 8197-8202.

5. Hocking, J., Priyadarshini, R., Takacs, C. N., Costa, T., Dye, N. A., Shapiro, L., Vollmer, W. and Jacobs-Wagner, C. (2012). Osmolality-dependent relocation of penicillin-binding protein PBP2 to the division site in Caulobacter crescentus. J Bacteriol 194(12): 3116-3127.

6. Potluri, L., Karczmarek, A., Verheul, J., Piette, A., Wilkin, J. M., Werth, N., Banzhaf, M., Vollmer, W., Young, K. D., Nguyen-Disteche, M. and den Blaauwen, T. (2010). Septal and lateral wall localization of PBP5, the major D,D-carboxypeptidase of Escherichia coli, requires substrate recognition and membrane attachment. Mol Microbiol 77(2): 300-323.

7. Typas, A., Banzhaf, M., van den Berg van Saparoea, B., Verheul, J., Biboy, J., Nichols, R. J., Zietek, M., Beilharz, K., Kannenberg, K., von Rechenberg, M., Breukink, E., den 
Blaauwen, T., Gross, C. A. and Vollmer, W. (2010). Regulation of peptidoglycan synthesis by outer-membrane proteins. Cell 143(7): 1097-1109.

8. van der Ploeg, R., Verheul, J., Vischer, N. O., Alexeeva, S., Hoogendoorn, E., Postma, M., Banzhaf, M., Vollmer, W. and den Blaauwen, T. (2013). Colocalization and interaction between elongasome and divisome during a preparative cell division phase in Escherichia coli. Mol Microbiol 87(5): 1074-1087. 